\title{
An empirical approach to marketing innovation in small and medium retailers: an application to the Spanish sector
}

\author{
Natalia Medranoํㅜ, Cristina Olarte-Pascual ${ }^{1}$
}

ABSTRACT

\begin{abstract}
Although numerous studies explore innovation, most of them focus on technological innovations. It is currently difficult to focus exclusively on products and processes when discussing innovation because new ideas can transform any part of an organization's value chain. Indeed, marketing innovation is essential for small and medium firms and its study is extremely important given the current lack of empirical evidence. Furthermore, the retail sector in Spain plays a significant role in the country's economy due to its contribution to gross domestic product and employment and to its role in the growth of cities and regions. In this context, the present study analyzes the determinants of marketing innovation practices of small and medium retailers and the relationships among the four types of innovation (product, process, organizational and marketing) to improve our understanding of marketing innovations in the retail sector. This study uses secondary data on innovation activity for Spanish companies in the years 2010-2012. Logistic regression models are estimated, and the results show that the introduction of new marketing methods has a positive impact on the propensity to engage in all other types of innovation (product, process and organizational). Furthermore, all of these methods positively impact the propensity to introduce marketing innovations. This study concludes with insights that can help managers to direct innovation processes in their companies and assist public administrators in the promotion of marketing innovations among small and medium retailers.
\end{abstract}

KEY WORDS: $\quad$ marketing innovation, non-technological innovations, retail, SME

JEL Classification: M310, O320

'Universidad de La Rioja, Spain

\section{Introduction}

Innovation is considered a decisive factor in wealth creation and a fundamental process for company competitiveness. Because of its importance, innova-

-

Correspondence concerning this article should be addressed to: Natalia Medrano Sáez, Edificio Quintiliano, C/ La Cigüeña 60, 26006 Logroño, La Rioja, Spain. E-mail: natalia.medrano@unirioja.es tion has been analyzed from various perspectives (e.g., Cooke, 2005; Crossan \& Apaydin, 2010; Porter, 1998), leading to multiple definitions and typologies (e.g., Armbruster, Bikfalvi, Kinkel, \& Lay, 2008; Becheikh, Landry, \& Amara, 2006; Francis \& Bessant, 2005; Garcia \& Calantone, 2002; Oke, 2007; Rowley, Baregheh, \& Sambrook, 2011; Schumpeter, 2012). Most of the numerous studies on innovation focus on technological innovations. However, it is currently difficult to limit 
the discussion of innovation to product and process innovations because new ideas can transform any part of an organization's value chain. For this reason, the definition proposed by the OECD/Eurostat (2005) in the Oslo Manual, which is recognized as an international reference, identifies four areas of innovation: product, process, organizational and marketing.

The lack of empirical evidence in the literature on the impact of marketing innovations - despite the fact that their effects differ from those of innovations in areas such as products and processes - is noteworthy. Additionally, marketing methods and tools play important roles in the evolution of industries (e.g., Bhaskaran, 2006; Chen, 2006; Rammer, Czarnitzki, \& Spielkamp, 2009; Schubert, 2010).

Spanish public policy has placed particular importance on supporting small and medium enterprises (SMEs) because these firms are the backbone of industry. Moreover, marketing innovation is essential for small firms to transform products into profit (Soltani, Azadi, Hosseini, Witlox, \& Passel, 2015). The tendency to engage in marketing innovation depends on the activities of an enterprise, and differences between the manufacturing and service sectors are significant (Medrano \& Olarte-Pascual, 2016). Companies in the service sector are more likely than those in the manufacturing sector to innovate in the areas of promotion, placement and price. Within the service sector, studies of the Spanish retail sector are important due to the significant contributions retail businesses make to Spanish GDP and employment. Furthermore, the retail sector is key to the growth of cities and regions (Medrano, Olarte-Pascual, Pelegrín-Borondo, \& Sierra-Murillo, 2016). Taking into account the context in which small and medium retailers currently operate, as well as all of the public business programs launched to encourage firm innovation, an improved understanding of this situation is needed to create effective public policies for each type of business.

Thus, the objective of this paper is to understand marketing innovation and its determinants among small and medium retailers based on data from the Technological Innovation Panel (PITEC). More precisely, this study investigates (1) the factors influencing the four types of innovation (product, process, organizational and marketing) and (2) the relationships between marketing innovation and the other types of innovation.
This paper, which focuses on marketing innovation, is organized as follows: first, the concept of marketing innovation and its repercussions in the literature are discussed. Second, the sample and methodology employed are described. Finally, the results and conclusions of the study are presented.

\section{Theoretical framework and hypotheses}

The first studies of innovation focused on product innovation in the manufacturing context. Although the literature on innovation is abundant, most of it refers to product and process innovations, which are called technological innovations. Certain studies have attempted to relate technological and organizational innovation (e.g., Brown \& Duguid, 1991; Brown, 2002; Djellal \& Gallouj, 1999; Kishore \& McLean, 2002; Tether et al., 2002). However, non-technological innovations - i.e., marketing and organizational innovations - have generally been neglected in the literature.

Marketing innovation is defined as the "implementation of a new marketing method involving significant changes in product design and/or packaging, product placement, product promoting or pricing" (OECD/ Eurostat, 2005, p. 49). However, there was a significant change to the definition of innovation in the 2005 Oslo Manual. Previously, technological product and process innovations were defined as the two types of innovation considered in the measurement of innovation. In the third edition of the Oslo Manual, two other types of innovation were added at the same level as technological innovation: marketing innovation and organizational innovation.

According to Wang (2015), three main streams of marketing innovation studies are found in the literature. The first stream discusses the competitive advantages that can be achieved through marketing innovation. The second addresses the relationships between marketing innovations and the other innovation types. Finally, the third stream attempts to understand the characteristics of firms that adopt marketing innovations.

From the competitive advantage perspective, authors usually view marketing innovation as a type of incremental innovation (Grewal \& Tansuhaj, 2001; Naidoo, 2010) that enables small and medium companies to successfully compete with large businesses (Bhaskaran, 2006; O’Dwyer, Gilmore, \& Carson, 
2009a, 2009b; Rammer et al., 2009). Therefore, this research focuses on marketing innovation in small and medium enterprises. Furthermore, Bhaskaran (2006) and Rammer et al. (2009) note that small and medium enterprises, especially those in low- and mid-tech industries, may be more willing to engage in potentially less costly marketing innovations than in technological innovations. Hence, marketing innovation is more important for small and medium retailers.

\section{Relationships between marketing innovation and the other innovation types}

According to Walker (2004), innovation activities are thought to influence each other and thus need to be implemented in conjunction with each other. The disputed relationship between technological innovation and marketing innovation centers on whether they are complements or substitutes; according to Kijek (2013), it is quite intuitive that the introduction of a new process or product calls for changes in marketing strategies. For instance, a new product line often requires changes in packaging and sales channels. Lewis and Wackowski (2006) provide an example from the tobacco industry, in which the introduction of flavored cigarettes was intensively supported by marketing innovations. However, other authors argue that marketing innovations do more than merely support technological innovations (Bhaskaran, 2006 and Rammer et al., 2009). Following this reasoning, Schubert (2010) maintains that marketing innovations are, on average, complements - rather than substitutes - for technological innovations but notes that this relationship is sensitive to external and internal factors, such firm size and technological opportunities. However, this author argues that marketing innovations make product and process innovations more successful. Furthermore, Walker (2008) concludes that organizational, marketing and service (or product) innovations are interrelated in public organizations. In a study of manufacturing firms in Turkey, positive relationships were shown between organizational innovation and process innovation, organizational innovation and marketing innovation, process innovation and product innovation, and marketing innovation and product innovation (Gunday, Ulusoy, Kilic, \& Alpkan, 2011). Additionally, Soltani et al. (2015) show that although there is no direct cause-and-effect relationship between organizational and production innovation, both of these innovation types are influenced by marketing innovation.

Considering the existing literature on the relationships between marketing innovation and the other types of innovation, the following hypotheses are formulated:

H1. Marketing innovation in small and medium retailers is positively associated with product innovation.

H2. Marketing innovation in small and medium retailers is positively associated with process innovation.

H3. Marketing innovation in small and medium retailers is positively associated with organizational innovation.

\section{Features of firms that adopt marketing innovations}

In addition to researching interactions among innovation types since the official inclusion of other forms of innovation in the Oslo Manual, researchers have begun to examine the relation between marketing innovation and various other aspects of firms, such as size (e.g., Geldes \& Felzensztein, 2013; Halpern, 2010; Moreira, Silva, Simões \& Sousa, 2012), R\&D expenditure (e.g., T. Kijek, 2013; Moreira et al., 2012), personnel training (e.g., Geldes \& Felzensztein, 2013; Kijek, 2013; Moreira, Silva, Simões, \& Sousa, 2012), export activities (e.g., Geldes \& Felzensztein, 2013; Medrano \& Olarte-Pascual, 2016), class of company and cooperation (e.g., Geldes \& Felzensztein, 2013), market share (e.g., Camisón \& Villar-López, 2014; Schubert, 2010; Shergill \& Nargundkar, 2005), market concentration (e.g., Schubert, 2010), and group membership (e.g., Medrano \& Olarte-Pascual, 2016; Schubert, 2010), among other firm characteristics.

Several recent analyses of technological and marketing innovations not only focus on the direct relationship between these two types of innovation but also address the impact of technological innovation activities on the propensity to innovate in marketing (Kijek, Lisowski, \& Starzyńska, 2013; Moreira at al., 2012). Kijek (2013) finds that product innovations influence the decision to introduce marketing innovations; however, there is little support for the view that 
Table 1. Research technical specifications

\begin{tabular}{ll}
\hline Scope & Small and medium Spanish companies \\
Sample size & Retailers 463; Other sectors 5,511 \\
Region of study & Spain \\
Information compilation system & Self-administered postal questionnaire \\
Organization responsible for the questionnaire & National Statistics Institute \\
Reference period & $2010-2012$ \\
Statistical programs & SPSS 15.0, STATA SE 10.0 \\
\hline
\end{tabular}

process innovations induce marketing innovations. In Spain, enterprises that conduct product, process or organizational innovations are more likely to innovate in marketing (Medrano \& Olarte-Pascual, 2016). The findings of Soltani et al. (2015) for small food industries show that when product and organizational innovations increase, marketing innovation also increases. Hence, the following hypotheses are formulated for small and medium retailers:

H4. Small and medium retailers that conduct product innovations are more likely to innovate in marketing.

H5. Small and medium retailers that conduct process innovations are more likely to innovate in marketing.

H6. Small and medium retailers that conduct organizational innovations are more likely to innovate in marketing.

\section{Research methods}

\section{Survey}

Data from PITEC are used to conduct this study. This database follows the methodological guidance provided by the OECD in the Oslo Manual using two periodically published sources: the Innovation in Companies Survey of Spanish firms and the Statistics on R\&D Activities database. The technical characteristics of this study are shown in table 1 . The data include 5,974 small and medium companies, of which 463 companies are in the retail sector and the remaining 5,511 companies are in other sectors.

\section{Statistical methods}

To determine whether there is a multicollinearity problem, this study considers the tolerance and variance inflation factor (VIF). A tolerance smaller than 0.20 and/or a VIF of 5 or higher indicate a multicollinearity problem (O’Brien, 2007).

Considering the two aims of the study, the analysis is divided into two parts. In the first part, the probability that firms engage in each kind of innovation (product, process, organization and marketing) is examined to verify the relationship between marketing innovation and the other types of innovation. Logistic regression is selected because it adapts to all types of independent variables (metric and non-metric) and does not require multivariate normality (Hair, Black, Babin, Anderson, \& Tatham, 2006). The dependent variable in each model is binary (coded 0 if the company does not innovate and 1 if the company innovates), and the independent variables in the four models are the other types of innovation and the following firm characteristics: belonging to a business group, percentage of women employed, company market (local, national, EU or other), training, public financing, and company class (private, private with $<10 \%$ foreign capital, private with $10 \%$ to $50 \%$ foreign capital, private with $>50 \%$ foreign capital). Additionally, for each dependent variable, the marginal effects are estimated. In the second part of this study, the probability that firms conduct each kind of marketing innovation is estimated using the same method (that is, using four binary logistic regressions) to verify the determinants of the four types of marketing innovation. 
Table 2. Number of small and medium companies that innovate in the retail and other sectors

\begin{tabular}{lcccc}
\hline & Retail & \multicolumn{2}{c}{ Other Sectors } \\
\hline Types of innovations & Innovate & $\%$ & Innovate & 28 \\
\hline General & 125 & 27 & 1560 & 17 \\
Marketing & 57 & 12 & 916 & 10 \\
Design & 50 & 11 & 544 & 15 \\
Pricing & 76 & 16 & 851 & 13 \\
Promotion & 73 & 16 & 722 & 42 \\
Placement & 114 & 25 & 2291 & 41 \\
Product & 121 & 26 & 2281 & 40 \\
Process & 155 & 100 & 2185 & 100 \\
Organizational & 463 & 5511 & \\
Total Companies & & 33 & & 13 \\
\hline
\end{tabular}

Table 3. Multicollinearity diagnosis indexes for independent variables

\begin{tabular}{lcc}
\hline Independent Variables & Tolerance & VIF \\
\hline Marketing & 0.775 & 1.289 \\
Product & 0.719 & 1.390 \\
Process & 0.767 & 1.312 \\
Organization & 0.761 & 1.028 \\
Group & 0.972 & 1.037 \\
Employment_women & 0.963 & 1.275 \\
Local Market & 0.784 & 1.713 \\
National Market & 0.583 & 1.503 \\
EU Market & 0.665 & 1.189 \\
Other Country Markets & 0.840 & 1.091 \\
Training & 0.915 & 1.176 \\
Public_Finan (Local) & 0.849 & 1.084 \\
Public_Finan (National) & 0.921 & 1.361 \\
Public_Finan (EU) & 0.734 & 1.289 \\
Company Class & 0.775 & \\
\hline
\end{tabular}

\section{Results and discussion}

The database provides a sample of 463 companies, with just over one-quarter $(27 \%)$ reporting that they implemented marketing innovation activities (table 2). However, the data show the importance of the retail sector because this sector does not exhibit the same average behavior as other sectors. In other sectors, marketing innovation is the least frequently implemented innovation of the four types of innovation. In contrast, our analysis of the retail sector shows that marketing 
Table 4. Logistic regression for types of innovation in small and medium retailers

\begin{tabular}{|c|c|c|c|c|c|c|c|c|}
\hline \multirow{3}{*}{ Variables } & \multicolumn{8}{|c|}{ Innovations } \\
\hline & \multicolumn{2}{|c|}{ Marketing } & \multicolumn{2}{|c|}{ Product } & \multicolumn{2}{|c|}{ Process } & \multicolumn{2}{|c|}{ Organization } \\
\hline & B & $d y / d x$ & $\beta$ & $d y / d x$ & $\beta$ & $d y / d x$ & B & $d y / d x$ \\
\hline \multicolumn{9}{|l|}{ Innovations } \\
\hline Marketing & & & $1.56^{* * *}$ & 0.28 & $0.99^{* * *}$ & 0.19 & $2.19^{* * *}$ & 0.48 \\
\hline Product & $1.54^{* * *}$ & 0.28 & & & 0.23 & 0.04 & 0.29 & 0.06 \\
\hline Process & $1.00^{* * *}$ & 0.17 & 0.27 & 0.04 & & & $0.94^{* * *}$ & 0.21 \\
\hline Organization & $2.20^{* * *}$ & 0.40 & 0.27 & 0.04 & $0.91^{* * *}$ & 0.16 & & \\
\hline \multicolumn{9}{|l|}{ Firm Characteristics } \\
\hline Group & 0.09 & 0.01 & -0.21 & -0.03 & 0.34 & 0.05 & $0.49 *$ & 0.10 \\
\hline Employment_women & $0.01 *$ & 0.00 & 0.00 & 0.00 & -0.00 & -0.00 & -0.00 & -0.00 \\
\hline \multicolumn{9}{|l|}{ Market } \\
\hline Local Market & -0.73 & -0.13 & 1.64 & 0.14 & 0.97 & 0.12 & -0.17 & -0.03 \\
\hline National Market & 0.65 & 0.08 & $1.19^{*}$ & 0.13 & $1.07^{* *}$ & 0.14 & -0.40 & -0.09 \\
\hline EU Market & $-0.67^{*}$ & -0.11 & $0.79^{* *}$ & 0.10 & 0.09 & 0.01 & $0.82^{* *}$ & 0.16 \\
\hline Other Country Markets & $0.82^{* * *}$ & 0.12 & -0.20 & -0.02 & $-0.54^{*}$ & -0.09 & -0.25 & -0.05 \\
\hline Training & 0.32 & 0.05 & 0.43 & 0.07 & $3.08^{* * *}$ & 0.64 & 0.70 & 0.16 \\
\hline Public_Finan (Local) & -0.95 & -0.11 & $1.23^{* *}$ & 0.24 & $0.99^{*}$ & 0.21 & $1.76^{* * *}$ & 0.41 \\
\hline Public_Finan (National) & -0.00 & -0.00 & $2.63^{* * *}$ & 0.56 & 0.75 & 0.15 & -0.00 & -0.00 \\
\hline Public_Finan (EU) & $-2.90 * *$ & -0.18 & $2.50^{* *}$ & 0.54 & 2.05 & 0.46 & 0.60 & 0.13 \\
\hline \multicolumn{9}{|l|}{ Company Class } \\
\hline Private & 0.24 & 0.03 & $-0.76^{* *}$ & -0.13 & 0.54 & 0.08 & 0.23 & 0.04 \\
\hline Private (<10\% Foreign Capital) & $1.69^{*}$ & 0.36 & -1.03 & -0.11 & -1.95 & -0.18 & -0.33 & -0.06 \\
\hline Private (10\% to $50 \%$ Foreign Capital) & -2.02 & -0.16 & $2.34^{* *}$ & 0.51 & 1.13 & 0.24 & -0.35 & -0.06 \\
\hline Pseudo-R2 & \multicolumn{2}{|c|}{46.5} & \multicolumn{2}{|c|}{39.7} & \multicolumn{2}{|c|}{34.6} & \multicolumn{2}{|c|}{40.6} \\
\hline$\%$ Correct Predictions & \multicolumn{2}{|c|}{81.2} & \multicolumn{2}{|c|}{81.4} & \multicolumn{2}{|c|}{78.8} & \multicolumn{2}{|c|}{79.7} \\
\hline
\end{tabular}

Note: ${ }^{*}$ Statistically significant at the 0.1 level, ${ }^{* *}$ statistically significant at the 0.05 level, ${ }^{* * *}$ statistically significant at the 0.01 level.

innovation ranks second behind organizational innovation. Differences in terms of the importance assigned to different types of marketing innovation are also observed. Design innovation is the most important, on average, in other sectors, whereas promotion and placement are the most frequently conducted activities in the retail sector.

When all independent variables are included in the analysis, table 3 shows that none has a tolerance less than 0.70 and there is no VIF higher than 2 . In conclusion, multicollinearity is not an issue in this study.
Table 4 presents the estimation results of the logistic regressions for the four types of innovation in small and medium retailers. First, the results show that the introduction of new marketing methods has a positive impact on the propensity to conduct all other types of innovations (product, process and organizational). Thus, $\mathrm{H} 1, \mathrm{H} 2$ and $\mathrm{H} 3$ are supported. Second, the results show that introducing new product, process and organizational methods has a positive impact on the propensity to conduct marketing innovations, confirming the results obtained by Wang (2015). These results also support 
Table 5. Logistic regression for types of marketing innovation in small and medium retailers

\begin{tabular}{|c|c|c|c|c|c|c|c|c|}
\hline \multirow{3}{*}{ Variables } & \multicolumn{8}{|c|}{ Marketing Innovations } \\
\hline & \multicolumn{2}{|c|}{ Design } & \multicolumn{2}{|c|}{ Pricing } & \multicolumn{2}{|c|}{ Promotion } & \multicolumn{2}{|c|}{ Placement } \\
\hline & B & $d y / d x$ & $\beta$ & $d y / d x$ & B & $d y / d x$ & B & $\mathrm{dy} / \mathrm{dx}$ \\
\hline \multicolumn{9}{|l|}{ Innovations } \\
\hline Design & & & 0.61 & 0.02 & 0.39 & 0.02 & $1.45^{* * *}$ & 0.13 \\
\hline Pricing & 0.47 & 0.02 & & & $2.33^{* * *}$ & 0.31 & 0.64 & 0.04 \\
\hline Promotion & 0.35 & 0.01 & $2.26^{* * *}$ & 0.19 & & & $3.23^{* * *}$ & 0.44 \\
\hline Placement & $1.53^{* * *}$ & 0.11 & 0.68 & 0.03 & $3.28^{* * *}$ & 0.48 & & \\
\hline Product & $1.75^{* * *}$ & 0.12 & -0.01 & -0.00 & -0.06 & -0.00 & 0.58 & 0.03 \\
\hline Process & $0.88^{* *}$ & 0.04 & 0.57 & 0.02 & 0.54 & 0.03 & -0.09 & -0.00 \\
\hline Organization & $0.92^{* *}$ & 0.04 & $1.24^{* * *}$ & 0.06 & $1.13^{* * *}$ & 0.08 & $1.09^{* * *}$ & 0.07 \\
\hline \multicolumn{9}{|l|}{ Firm Characteristics } \\
\hline Group & 0.29 & 0.01 & 0.13 & 0.00 & -0.05 & -0.00 & -0.36 & -0.01 \\
\hline Employment_women & 0.01 & 0.00 & 0.01 & 0.00 & 0.00 & 0.00 & -0.00 & -0.00 \\
\hline \multicolumn{9}{|l|}{ Market } \\
\hline Local Market & $-1.90^{* * *}$ & -0.18 & 0.67 & 0.02 & -0.94 & -0.08 & 1.54 & 0.04 \\
\hline National Market & 0.12 & 0.00 & 0.41 & 0.01 & -0.25 & -0.01 & $1.57^{*}$ & 0.05 \\
\hline EU Market & $1.09^{* *}$ & 0.04 & $-1.06^{* *}$ & -0.04 & -0.08 & -0.00 & -0.68 & -0.04 \\
\hline Other Country Markets & 0.11 & 0.00 & -0.04 & -0.00 & 0.15 & 0.00 & $0.95^{* *}$ & 0.05 \\
\hline Training & -1.13 & -0.03 & 0.75 & 0.04 & -0.04 & -0.00 & 0.00 & 0.00 \\
\hline Public_Finan (Local) & 0.56 & 0.03 & $-1.54^{*}$ & -0.03 & -0.87 & -0.03 & 0.25 & 0.01 \\
\hline Public_Finan (National) & -0.06 & -0.00 & 0.04 & 0.00 & 0.38 & 0.02 & 0.28 & 0.01 \\
\hline Public_Finan (EU) & (omitted) & & 1.29 & 0.09 & (omitted) & & 1.01 & 0.08 \\
\hline \multicolumn{9}{|l|}{ Company Class } \\
\hline Private & -0.11 & -0.00 & -0.04 & -0.00 & $1.24^{* *}$ & 0.05 & $-1.17^{* *}$ & -0.09 \\
\hline Private (<10\% Foreign Capital) & 1.49 & 0.12 & 1.55 & 0.12 & $2.37^{* *}$ & 0.35 & (omitted) & \\
\hline Private (10\% to 50\% Foreign Capital) & (omitted) & & 0.62 & 0.03 & 0.28 & 0.01 & -1.11 & -0.03 \\
\hline Pseudo-R2 & \multicolumn{2}{|c|}{46.8} & \multicolumn{2}{|c|}{46.2} & \multicolumn{2}{|c|}{62.3} & \multicolumn{2}{|c|}{59.8} \\
\hline$\%$ Correct Predictions & \multicolumn{2}{|c|}{89.2} & \multicolumn{2}{|c|}{90.5} & \multicolumn{2}{|c|}{91.1} & \multicolumn{2}{|c|}{89.8} \\
\hline
\end{tabular}

Note: *Statistically significant at the 0.1 level, ${ }^{* *}$ statistically significant at the 0.05 level, ${ }^{* * *}$ statistically significant at the 0.01 level.

Soltani et al. (2015) because there are significant positive cause-and-effect relationships between product and organizational innovations and marketing innovations in the studied firms. This result is also consistent with Kijek (2013), who establishes that product innovations influence the decision to introduce marketing innovations, suggesting a complementary relationship and a positive impact of product innovation on marketing innovation. However, this result conflicts with the results of Geldes and Felzensztein (2013), who find a statistically significant negative relation between marketing and product innovation in the agribusiness sector. 
For the specific case of marketing innovation in small and medium retailers, statistically significant positive relations are obtained for the employment of women, other country markets and private companies $(<10 \%$ foreign capital) and negative relations are obtained for the EU market and EU public financing. For product innovations, positive relations with the EU market and public financing are obtained, with negative relations for private companies $(<10 \%$ foreign capital). With regard to process innovations, statistically significant positive relations are obtained for the national market, training and local public financing, with a negative relation for other country markets. Kijek et al. (2013) also find evidence that expenditures on training positively affect the implementation of marketing innovations in enterprises. However, in this case, the statistically significant positive relation is with process innovation rather than marketing innovation. Additionally, among small and medium retailers, organizational innovations have a statistically significant positive relation with the EU market, local public financing and group membership.

Table 5 presents the estimation results of the logistic regressions for four types of marketing innovation in small and medium retailers. Model 1 considers the percentage of firms that introduced design innovation as the response variable; models 2, 3 and 4 consider the same thing for pricing, promotion and placement innovation, respectively.

The results show that the introduction of new organizational methods has a positive impact on the propensity of small and medium retailers to engage in all types of marketing innovations. Thus, H6 is supported for all types of marketing innovations, confirming the results of Soltani et al. (2015). However, the introduction of new products or processes has a significant positive impact only on the propensity to conduct design innovation. The effects on the implementation of changes in sales channels, pricing methods and promotion are insignificant. Thus, H4 and H5 are only partially supported. The results partially support the finding of both Kijek (2013) and Medrano and Olarte-Pascual (2016) that the introduction of new products has a positive impact on the propensity to engage in all types of marketing innovation. Soltani et al. (2015) show that when product innovation increases, marketing innovation also increases. Thus, for small and medium retailers, the introduction of new products induces changes only in design innovation.

For the specific case of design innovation, a statistically significant positive relation with the EU market is observed, whereas the relation with the local market is negative. For pricing innovation, negative relations with the EU market and public financing (local) are observed. For promotion innovation, statistically significant positive relations with private companies and private companies $(<10 \%$ foreign capital) are obtained. Additionally, placement innovation has a statistically significant positive relation with the national market and training and a negative relation with private companies.

\section{Conclusions}

In the modern world, it is undeniable that globalization, stronger competition, increasingly stringent and segmented demand, rapid technological evolution and increasingly shorter life cycles have led to substantial growth in the relevance of innovation as a key factor in achieving leverage in the market. These obvious changes in both society and consumer behavior render previously appropriate models unsuitable in current conditions, and the marketing discipline - like practical and scientific expertise - is not exempt from these changes. In the current scenario, small and medium retailers are losing customers every day; these stores eventually close, and over time, cities slowly lose their cultural and economic vibrancy (Medrano et al., 2016).

In this context, the present study analyzes the determinants of the marketing innovation practices of small and medium retailers and the relationships among the four types of innovation (product, process, organizational and marketing) in order to better understand marketing innovation in the retail sector.

The first result shows that marketing innovation is the second-most frequently implemented innovation by small and medium retailers, whereas in other sectors, marketing innovation is the least frequently implemented innovation of the four types of innovation. This result indicates the importance of marketing innovation in the retail sector and is consistent with Bhaskaran (2006) and Rammer et al. (2009), who note that small and medium enterprises, especially those 
in low- and mid-tech industries, may be more willing to engage in marketing innovation, which can be less costly than technological innovation.

The second result shows that the introduction of new marketing methods among small and medium retailers has a positive impact on the propensity to conduct all other types of innovation (product, process and organizational). However, introducing other types of innovation does not have the same impact. All other innovation types positively impact the propensity to introduce marketing innovations, albeit not of all types. We also conclude that product, process and organizational innovations present different determinants and different inter-relations among the different types of innovations.

The last result shows that the introduction of new organizational methods has a positive impact on the propensity of small and medium retailers to conduct all types of marketing innovation (design, pricing, promotion and placement). However, the introduction of new products or processes only has a positive impact on the propensity to conduct design innovations. Thus, we conclude that the determinants of marketing innovation differ among the four types of marketing innovation in the retail sector.

In conclusion, it is important to highlight that the included types of innovation (marketing, organizational, process and products), as well as the various types of marketing innovation (design, pricing, promotion and placement), have different determinants, and the relationships among the different types of innovations vary. These results confirm the findings of Rammer et al. (2009), Mothe and Nguyen-Thi (2012), Mothe and Thi (2010) and Geldes and Felzensztein (2013). There is a need for further study of individual firms and their inter-relations across different economic and territorial sectors (Crossan \& Apaydin, 2010).

These results can help managers and public administrators to undertake actions that promote innovation. According to Medrano and Olarte-Pascual (2016), the tendency to engage in marketing innovation depends on the activity of an enterprise, and the differences between the manufacturing sector and the service sector are significant. Furthermore, Bhaskaran (2006) and Rammer et al. (2009) note that small and medium enterprises, especially those in low- and mid-tech industries, might be more willing to engage in marketing innovation, which might be less costly than technological innovation. Hence, marketing innovation becomes more important for small and medium retailers.

This paper cannot be concluded without noting the limitations of the study. The first limitation stems from the use of a pre-prepared database (PITEC). It was not possible to work with all the suitable variables or to measure the "marketing innovation" variable in a more appropriate manner. Additionally, the models presented in this paper exhibit acceptable overall significance of the parameters and high percentages of correct predictions. The adjustments of the pseudo- $\mathrm{R}^{2}$ models were between $34.6 \%$ and $62.3 \%$. These adjustments were expected because most of our variables are qualitative.

These limitations open up various paths for further research. First, it would be interesting to analyze a longer time span using panel data, as Guisado González and Coca Pérez (2015) recommend. In addition, this study could be extended by breaking down the "market" variable more precisely. The "other countries" variable in this paper covers a very wide range of countries with vastly different cultures and thus it would be interesting to look more deeply into this aspect. Finally, research into the concept of "marketing innovation" remains interesting because it is not clear what companies mean by "marketing innovation". To this end, it might be a good idea to develop an ad hoc measuring system that would allow us to understand occurrences in marketing more fully through the possibilities offered by new technologies with a multitude of new systems for customer relations.

\section{References}

Armbruster, H., Bikfalvi, A., Kinkel, S., \& Lay, G. (2008). Organizational innovation: The challenge of measuring non-technical innovation in largescale surveys. Technovation, 28(10), 644-657. doi:10.1016/j.technovation.2008.03.003

Becheikh, N., Landry, R., \& Amara, N. (2006). Lessons from innovation empirical studies in the manufacturing sector: A systematic review of the literature from 1993-2003. Technovation, 26(5), 644-664.

Bhaskaran, S. (2006). Incremental innovation and business performance: Small and medium-size food enterprises in a concentrated industry environment. Journal of Small Business Management, 44(1), 6480. doi:10.1111/j.1540-627X.2006.00154.x 
Brown, J. S. (2002). Research that reinvents the corporation. Harvard Business Review, 80(8), 105-114.

Brown, J. S., \& Duguid, P. (1991). Organizational learning and communities-of-practice: Toward a unified view of working, learning, and innovation. Organization Science, 2(1), 40-57. doi:10.1287/orsc.2.1.40

Camisón, C., \& Villar-López, A. (2014). Organizational innovation as an enabler of technological innovation capabilities and firm performance. Journal of Business Research, 67(1), 2891-2902. doi:10.1016/j.jbusres.2012.06.004

Chen, Y. (2006). Marketing innovation. Journal of Economics and Management Strategy, 15(1), 101-123. doi:10.1111/j.1530-9134.2006.00093.x

Cooke, P. (2005). Regionally asymmetric knowledge capabilities and open innovation. Exploring 'Globalisation 2' - A new model of industry organization. Research Policy, 34(8), 1128-1149. doi:10.1016/j.respol.2004.12.005

Crossan, M. M., \& Apaydin, M. (2010). A multi-dimensional framework of organizational innovation: A systematic review of the literature. Journal of Management Studies, 47(6), 1154-1191. doi:10.1111/j.1467-6486.2009.00880.x

Djellal, F., \& Gallouj, F. (1999). Services and the search for relevant innovation indicators: A review of national and international surveys. Science and Public Policy, 26(4), 218-232. doi:10.3152/147154399781782400

Francis, D., \& Bessant, J. (2005). Targeting innovation and implications for capability development. Technovation, 25(3), 171-183. doi:10.1016/j.technovation.2004.03.004

Garcia, R., \& Calantone, R. (2002). A critical look at technological innovation typology and innovativeness terminology: A literature review. Journal of Product Innovation Management, 19(2), 110132. doi:10.1111/1540-5885.1920110

Geldes, C., \& Felzensztein, C. (2013). Marketing innovations in the agribusiness sector. Academia Revista Latinoamericana de Administración, 26(1), 108-138. doi:10.1108/ARLA-05-2013-0042

Grewal, R., \& Tansuhaj, P. (2001). Building organizational capabilities for managing economic crisis: The role of market orientation and strategic flexibility. Journal of Marketing, 65(2), 67-80. doi:10.1509/jmkg.65.2.67.18259
Guisado González, M., \& Coca Pérez, J. L. (2015). Complementarity between different types of innovation: An oasis in the middle of the desert. Esic Market 152, 46(3), 9-56.

Gunday, G., Ulusoy, G., Kilic, K., \& Alpkan, L. (2011). Effects of innovation types on firm performance. International Journal of Production Economics, 133(2), 662-676. doi:10.1016/j.ijpe.2011.05.014

Hair, J. F., Black, W. C., Babin, B. J., Anderson, R. E., \& Tatham, R. L. (2006). Multivariate data analysis (6th ed.). Upper Saddle River, NJ: Pearson Prentice-Hall.

Halpern, N. (2010). Marketing innovation: Sources, capabilities and consequences at airports in Europe's peripheral areas. Journal of Air Transport Management, 16(2), 52-58. doi:10.1016/j.jairtraman.2009.10.002

Kijek, A., Lisowski, M., \& Starzyńska, W. (2013). Innovation Activity of the Polish Manufacturing Enterprises. International Advances in Economic Research, 19(1), 33-43. doi:10.1007/s11294-012-9387-7

Kijek, T. (2013). An empirical analysis of the relationship between technological and marketing innovations: A Case of Polish manufacturing firms. Acta Scientiarum Polonorum. Oeconomia, 12(2), 15-25.

Kishore, R., \& McLean, E. R. (2002). The next generation enterprise: A CIO perspective on the vision, its impacts, and implementation challenges. Information Systems Frontiers, 4(1), 121-138. doi:10.1023/A:1015303109679

Lewis, M. J., \& Wackowski, O. (2006). Dealing with an innovative industry: A look at flavored cigarettes promoted by mainstream brands. American Journal of Public Health, 96(2), 244-251. doi:10.2105/ AJPH.2004.061200

Medrano, N., \& Olarte-Pascual, C. (2016). The effects of the crisis on marketing innovation: An application for Spain. Journal of Business \& Industrial Marketing, 31(3), 404-417. doi:10.1108/JBIM-02-2013-0048

Medrano, N., Olarte-Pascual, C., Pelegrín-Borondo, J., \& Sierra-Murillo, Y. (2016). Consumer behavior in shopping streets: The importance of the salesperson's professional personal attention. Frontiers in Psychology, 7. doi:10.3389/fpsyg.2016.00125

Moreira, J., Silva, M. J., Simões, J., \& Sousa, G. (2012). Drivers of marketing innovation in portuguese firms. Amfiteatru Economics, 14(31), 195-206. 
Mothe, C., \& Nguyen Thi, T. U. (2012). Non-technological and technological innovations: Do services differ from manufacturing? An empirical analysis of Luxembourg firms. International Journal of Technology Management, 57(4), 227-244. doi:10.1504/IJTM.2012.045544

Mothe, C., \& Nguyen Thi, T. U. (2010). The link between non-technological innovations and technological innovation. European Journal of Innovation Management, 13(3), 313-332. doi:10.1108/14601061011060148

Naidoo, V. (2010). Firm survival through a crisis: The influence of market orientation, marketing innovation and business strategy. Industrial Marketing Management, 39(8), 1311-1320. doi:10.1016/j.indmarman.2010.02.005

O’Brien, R. M. (2007). A caution regarding rules of thumb for variance inflation factors. Quality and Quantity, 41(5), 673-690. doi:10.1007/s11135006-9018-6

O'Dwyer, M., Gilmore, A., \& Carson, D. (2009a). Innovative marketing in SMEs. European Journal of Marketing, 43(1-2), 46-61. doi:10.1108/03090560910923238

O’Dwyer, M., Gilmore, A., \& Carson, D. (2009b). Innovative marketing in SMEs: A theoretical framework. European Business Review, 21(6), 504-515. doi:10.1108/09555340910998805

OECD/Eurostat. (2005). Oslo Manual: Guidelines for collecting and interpreting innovation data (3rd ed.). Paris: OECD Publishing. Available from http://www.oecd-ilibrary.org/science-and-technology/oslo-manual_9789264013100-en Oke, A. (2007). Innovation types and innovation management practices in service companies. International Journal of Operations \& Production Management, 27(6), 564-587. doi:10.1108/01443570710750268

Porter, M. E. (1998). Clusters and the new economics of competition. Harvard Business Review, 76(6), 77-90. Rammer, C., Czarnitzki, D., \& Spielkamp, A. (2009). Innovation success of non-R\&D-performers: Substituting technology by management in SMEs. Small Business Economics, 33(1), 35-58. doi:10.1007/s11187-009-9185-7

Rowley, J., Baregheh, A., \& Sambrook, S. (2011). Towards an innovation-type mapping tool. Management Decision, 49(1), 73-86. doi:10.1108/00251741111094446
Schubert, T. (2010). Marketing and organisational innovations in entrepreneurial innovation processes and their relation to market structure and firm characteristics. Review of Industrial Organization, 36(2), 189-212. doi:10.1007/s11151-010-9243-y

Schumpeter, J. A. (2012). The theory of economic development. An inquiry into profits, capital, credit, interest, and the business cycle (16th ed.). New Brunswick, NJ: Transaction Publishers.

Shergill, G. S., \& Nargundkar, R. (2005). Market orientation, marketing innovation as performance drivers. Journal of Global Marketing, 19(1), 27-47. doi:10.1300/J042v19n01_03

Soltani, S., Azadi, H., Hosseini, S. J. F., Witlox, F., \& Passel, Van Passel, S. (2015). Marketing innovation in rural small food industries in Iran. Journal of Food Products Marketing, 21(5), 533-551. doi:10 $.1080 / 10454446.2015 .1041196$

Tether, B., Miles, I., Blind, K., Hipp, C., de Liso, N., \& Cainelli, G. (2002). Innovation in the service sector: Analysis of data collected under the Community Innovation Survey (CIS-2). Manchester, UK: The University of Manchester \& UMIST.

Walker, R. M. (2004). Innovation and organisational performance: Evidence and a research agenda (Research Paper No. 002). Advanced Institute of Management. doi:10.2139/ssrn.1306909

Walker, R. M. (2008). An empirical evaluation of innovation types and organizational and environmental characteristics: Towards a configuration framework. Journal of Public Administration Research and Theory, 18(4), 591-615. doi:10.1093/ jopart/mum026

Wang, S. (2015). What motivates marketing innovation and whether marketing innovation varies across industry sectors (Postdoctoral thesis, Telfer School of Management, University of Ottawa). Retrieved from https://www.ruor.uottawa.ca/bitstream/10393/33008/1/Wang_Shu_2015_Thesis.pdf

\section{Acknowledgements}

This work was funded by the Cátedra de Comercio of Universidad de La Rioja. 
